\title{
SARS-CoV-2 vaccine effectiveness in immunosuppressed kidney transplant recipients
}

Hiam Chemaitelly, MSc ${ }^{1,2}$; Sawsan AlMukdad, MSc${ }^{1,2}$; Jobin Paravila Joy, BScN ${ }^{3}$; Houssein H. Ayoub, $\mathrm{PhD}^{4}$; Hadi M. Yassine, $\mathrm{PhD}^{5,6}$; Fatiha M. Benslimane, $\mathrm{PhD}^{5,6}$; Hebah A. Al Khatib, $\mathrm{PhD}^{5,6}$; Patrick Tang, MD PhD ${ }^{7}$; Mohammad R. Hasan, $\mathrm{PhD}^{7}$; Peter Coyle, $\mathrm{MD}^{3,5,8}$; Zaina Al Kanaani, $\mathrm{PhD}^{3}$; Einas Al Kuwari, $\mathrm{MD}^{3}$; Andrew Jeremijenko, $\mathrm{MD}^{3}$; Anvar Hassan Kaleeckal, MSc ${ }^{3}$; Ali Nizar Latif, MD ${ }^{3}$; Riyazuddin Mohammad Shaik, MSc ${ }^{3}$; Hanan F. Abdul Rahim, $\mathrm{PhD}^{9}$, Gheyath K. Nasrallah, PhD ${ }^{5,6}$, Mohamed Ghaith Al Kuwari, MD ${ }^{10}$, Adeel A. Butt, MBBS MS $^{3,11}$; Hamad Eid Al Romaihi, MD ${ }^{12}$; Mohamed H. Al-Thani, MD ${ }^{12}$; Mohamad M. Alkadi, $\mathrm{MD}^{3}$; Omar Ali, MD ${ }^{3}$; Muna Al-Maslamani, $\mathrm{MD}^{3}$; Roberto Bertollini, MD MPH ${ }^{12}$; Hassan Al

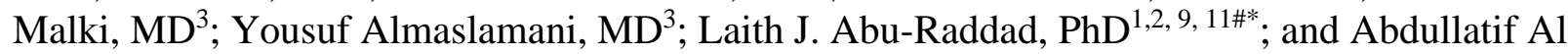
Khal, $\mathrm{MD}^{3 \#}$

${ }^{\#}$ Both authors are joint senior authors in this study.

${ }^{1}$ Infectious Disease Epidemiology Group, Weill Cornell Medicine-Qatar, Cornell University, Doha, Qatar

${ }^{2}$ World Health Organization Collaborating Centre for Disease Epidemiology Analytics on HIV/AIDS, Sexually Transmitted Infections, and Viral Hepatitis, Weill Cornell Medicine-Qatar, Cornell University, Qatar Foundation - Education City, Doha, Qatar

${ }^{3}$ Hamad Medical Corporation, Doha, Qatar

${ }^{4}$ Department of Mathematics, Statistics, and Physics, Qatar University, Doha, Qatar

${ }^{5}$ Biomedical Research Center, Member of QU Health, Qatar University, Doha, Qatar

${ }^{6}$ Department of Biomedical Science, College of Health Sciences, Member of QU Health, Qatar University, Doha, Qatar

${ }^{7}$ Department of Pathology, Sidra Medicine, Doha, Qatar

${ }^{8}$ Wellcome-Wolfson Institute for Experimental Medicine, Queens University, Belfast, United

Kingdom

${ }^{9}$ Department of Public Health, College of Health Sciences, QU Health, Qatar University, Doha, Qatar

${ }^{10}$ Primary Health Care Corporation, Doha, Qatar

${ }^{11}$ Department of Population Health Sciences, Weill Cornell Medicine, Cornell University, New York, New York, USA

${ }^{12}$ Ministry of Public Health, Doha, Qatar

Word count: Abstract: 207 words, Main Text: 2,167 words.

Number of tables: 1 .

Number of figures: 4 .

Running head: Vaccine effectiveness in organ transplant recipients.

Keywords: SARS-CoV-2; COVID-19; vaccine; cohort study; kidney; transplantation; immune suppression; immunity; epidemiology.

*Correspondence to Professor Laith J. Abu-Raddad, E-mail: 1ja2002@ qatar-med.cornell.edu. 
medRxiv preprint doi: https://doi.org/10.1101/2021.08.07.21261578; this version posted August 9, 2021. The copyright holder for this preprint (which was not certified by peer review) is the author/funder, who has granted medRxiv a license to display the preprint in perpetuity.

All rights reserved. No reuse allowed without permission.

\begin{abstract}
COVID-19 vaccine protection against infection in immunosuppressed solid organ transplant recipients is unknown but possibly weak with the low proportion of these patients mounting a robust humoral and cellular immune response after vaccination. Using a retrospective cohort study design with cross-over, we assessed vaccine effectiveness among 782 kidney transplant recipients registered at Hamad Medical Corporation, the national public healthcare provider in Qatar, where the BNT162b2 (Pfizer-BioNTech) and mRNA-1273 (Moderna) vaccines have been used in the national immunization campaign. Vaccine effectiveness against any SARS-CoV-2 infection was estimated at $46.6 \%(95 \%$ CI: 0.0-73.7\%) $\geq 14$ days after the second dose, $66.0 \%$ (95\% CI: $21.3-85.3 \%) \geq 42$ days after the second dose, and $73.9 \%(95 \%$ CI: $33.0-89.9 \%) \geq 56$ days after the second dose. Vaccine effectiveness against any severe, critical, or fatal COVID-19 disease was estimated at $72.3 \%$ (95\% CI: 0.0-90.9\%) $\geq 14$ days after the second dose, $85.0 \%$ (95\% CI: $35.7-96.5 \%) \geq 42$ days after the second dose, and $83.8 \%(95 \%$ CI: $31.3-96.2 \%) \geq 56$ days after the second dose. Most vaccine breakthrough infections occurred in the first few weeks after receiving the first and/or second dose. Vaccine effectiveness reached considerable levels in kidney transplant recipients, but vaccine protection mounted slowly and did not reach a high level until several weeks after the second dose.
\end{abstract}




\section{Introduction}

Coronavirus Disease 2019 (COVID-19) vaccine protection against infection in the immunosuppressed solid organ transplant recipients is unknown but suspected to be weak. ${ }^{1,2}$ Evidence indicates low proportion of these patients mounting a robust humoral and cellular immune response after vaccination. ${ }^{3-18}$ In this investigation, we assessed vaccine effectiveness in immunosuppressed kidney transplant recipients in Qatar, where the BNT162b2 ${ }^{19}$ (PfizerBioNTech) and mRNA-1273 ${ }^{20}$ (Moderna) vaccines have been the vaccines of choice in the national immunization campaign..$^{21-24}$

\section{Methods}

\section{Study population and databases}

We analyzed the kidney transplant database and the national federated Qatar severe acute respiratory syndrome coronavirus 2 (SARS-CoV-2) databases compiled at Hamad Medical Corporation, the main public healthcare provider and the nationally designated provider for all Coronavirus Disease 2019 (COVID-19) healthcare needs. Data were extracted directly from the integrated nationwide digital-health information platform that has captured all SARS-CoV-2related data in the population of Qatar since the start of the epidemic, including demographic characteristics, all records of polymerase-chain-reaction (PCR) testing (Supplementary Text 1), antibody testing, vaccination, COVID-19 hospitalizations, and classification of infection severity and deaths per World Health Organization (WHO) guidelines (performed by trained medical personnel through individual chart reviews) ${ }^{25,26}$ (Supplementary Text 2). These databases are complete, with no missing information, since every test, vaccination, and hospitalization for SARS-CoV-2 in Qatar is registered using the Hamad Medical Corporation Number (national and 
medRxiv preprint doi: https://doi.org/10.1101/2021.08.07.21261578; this version posted August 9, 2021. The copyright holder for this preprint (which was not certified by peer review) is the author/funder, who has granted medRxiv a license to display the preprint in perpetuity.

All rights reserved. No reuse allowed without permission.

universal healthcare system number) and Qatar Identification Number in the national centralized SARS-CoV-2 databases.

\section{Study design}

We performed a retrospective cohort study with a cross-over design to estimate, for kidney transplant recipients, effectiveness of vaccination against SARS-CoV-2 infection as a primary outcome. The study compared incidence of infection in vaccinated persons and those unvaccinated between February 1-July 21, 2021, at a time when the country was undergoing two back-to-back SARS-CoV-2 waves dominated by the B.1.1.7 (Alpha ${ }^{27}$ ) and B.1.351 (Beta $\left.{ }^{27}\right)$ variants. $^{21,23,28-30}$ It is noteworthy that the first SARS-CoV-2 epidemic wave in Qatar occurred (before introduction of any variant of concern) and peaked in late May, 2020. ${ }^{31,32}$ The second wave was triggered by introduction and expansion of the B.1.1.7 variant and peaked in early March, 2021. ${ }^{21,23,28,29}$ The third wave was dominated by the B.1.351 variant, and peaked in the first week of April, 2021..$^{21,23,28,29}$ The B.1.617.2 $\left(\right.$ Delta $\left.^{27}\right)$ variant has been introduced more recently in Qatar, and as of July 28, 2021, it remains at low incidence. ${ }^{28,29}$ There is no evidence that any other variant of concern is or has been responsible for appreciable community transmission in Qatar. ${ }^{28,29}$

Individuals in the cohort of kidney transplant recipients were eligible for inclusion in the analysis if they had no prior PCR-confirmed diagnosis and were alive at the start of the follow-up time.

The time of follow up was from February 1 up to July 21, 2021. Individuals were followed from February 1, 2021 until documented (PCR-confirmed) infection, death, vaccination (for those unvaccinated), or end-of-study censoring (set at July 21, 2021). Reporting of the study followed the STROBE guidelines (Supplementary Table 1).

\section{Statistical analysis}


Descriptive statistical analysis (frequencies and measures of central tendency) was performed to describe vaccinated and unvaccinated cohorts. Covariate differences between cohorts were evaluated using t-tests for continuous variables and chi-square tests for categorical variables, with two-sided $\mathrm{p}$-value $<0.05$ indicating a statistically significant association.

Infection hazard ratios and associated 95\% confidence interval (CIs) were estimated using regressions applying the Fine-Gray model, ${ }^{33}$ with adjustment for age, sex, and nationality group, to control for differences in exposure risk ${ }^{31,32,34-37}$ and variant exposure ${ }^{21,28,29}$ by sex, age, and nationality. This was done using the STATA $17.0^{38}$ stcrreg command to account further for potential bias arising from the competing risks of vaccination and death, ${ }^{33}$ as the duration of follow up coincided with the rapid scale-up of vaccination in Qatar. Hazard ratios were subsequently used to derive vaccine effectiveness and its $95 \%$ CI using the equation, 1- hazard ratio. The $95 \%$ CIs were not adjusted for multiplicity. Interactions were not considered.

Adjusted curves for cumulative incidence were generated using the stcurve command, which fits a Fine-Gray model, ${ }^{33}$ with adjustment for age, sex, and nationality group, to account for potential bias arising from the competing risks of vaccination and death. In addition to the baseline analysis comparing incidence of documented infection in individuals who completed $\geq 14$ days after the second vaccine dose to that in the cohort of individuals with no vaccination record, two subgroup analyses were performed contrasting incidence in individuals who completed $\geq 42$ days and $\geq 56$ days after the second vaccine dose with that in the unvaccinated cohort.

In all analyses, nationality was categorized into: Bangladeshis, Indians, Nepalese, Pakistanis, and Sri Lankans (Group 1), Qataris (Group 2), and all other nationalities (Group 3). This categorization was informed by the observed epidemiology and exposure risk assessments of 
medRxiv preprint doi: https://doi.org/10.1101/2021.08.07.21261578; this version posted August 9, 2021. The copyright holder for this preprint (which was not certified by peer review) is the author/funder, who has granted medRxiv a license to display the preprint in perpetuity.

All rights reserved. No reuse allowed without permission.

SARS-CoV-2 infection in Qatar. ${ }^{31,32,34-37}$ Of note that Qatar has unique demographics where expatriates from over 150 countries comprise $89 \%$ of the population. ${ }^{31,39}$

Incidence rate of documented infection was calculated by dividing the number of infection cases identified during the study by the number of person-weeks contributed by all eligible individuals in the vaccinated and unvaccinated cohorts. The incidence rate and associated $95 \% \mathrm{CI}$ were estimated using a Poisson log-likelihood regression model with the stptime command. Follow-up person-time was calculated from study onset (February 1, 2021) until PCR-confirmed diagnosis of infection, all-cause death, vaccination (for those unvaccinated), or end-of-study censoring (July 21, 2021). Statistical analyses were conducted in STATA/SE version 17.0. ${ }^{38}$

\section{Ethical approval}

The study was approved by the Hamad Medical Corporation and Weill Cornell Medicine-Qatar Institutional Review Boards with waiver of informed consent.

\section{Results}

\section{Study population}

Incidence of documented SARS-CoV-2 infection, symptomatic or asymptomatic, was assessed in all immunosuppressed kidney transplant recipients $(n=782)$ registered and clinically followed at Hamad Medical Corporation, the national public healthcare provider in Qatar (Figure 1). Maintenance immune suppression regimens included azathioprine (9.6\%), cyclosporine (16.4\%), everolimus (0.2\%), mycophenolate mofetil (76.1\%), prednisolone $(82.5 \%)$, sirolimus $(4.2 \%)$, and tacrolimus (72.9\%). Out of the 782 transplant recipients, 601 (76.9\%) received at least one vaccine dose by the end of the study on July 21, 2021, of whom 559 (93.0\%) were vaccinated with BNT162b2 and $42(7.0 \%)$ with mRNA-1273. The median date of first vaccine dose was 
medRxiv preprint doi: https://doi.org/10.1101/2021.08.07.21261578; this version posted August 9, 2021. The copyright holder for this preprint (which was not certified by peer review) is the author/funder, who has granted medRxiv a license to display the preprint in perpetuity.

All rights reserved. No reuse allowed without permission.

February 2, 2021; and 48.3\% of individuals received one or both vaccine doses before start of follow-up on February 1, 2021.

Individuals in this cohort were followed from February 1, 2021 until documented (PCRconfirmed) infection, all-cause death, vaccination (for those unvaccinated), or end-of-study censoring (set at July 21, 2021; Figure 1). Individuals with a prior SARS-CoV-2 PCR-confirmed diagnosis $(n=71)$, or those who died before start of follow-up $(n=6)$, were excluded from analysis.

Figure 1 shows the process for identifying infections in unvaccinated and vaccinated persons, and Table 1 presents their demographic and clinical characteristics. The median time since transplantation was 7 years (interquartile range (IQR): 4-13). The median age of those unvaccinated was 49 years (IQR: 39-61) and 63.1\% were men, whereas among those vaccinated, the median age was 52 years (IQR: 40-61) and 70.4\% were men. Unvaccinated and vaccinated persons came from diverse national origins and were broadly representative of the unique demographics of the population of Qatar. ${ }^{31,39}$

\section{Vaccine effectiveness at $\geq 14$ days after the second dose}

Figure 2 shows the cumulative incidence of infection among those who completed $\geq 14$ days after the second vaccine dose compared to that in persons with no vaccination record, adjusting for age, sex, nationality group, and the competing risks of vaccination and death. Cumulative incidence in vaccinated and unvaccinated cohorts was assessed, respectively, at $2.58 \%$ (95\% confidence interval (CI): $1.41-4.35 \%$ ) versus $4.74 \%$ (95\% CI: 3.00-7.07\%), after 120 days of follow-up. Incidence rate of infection was estimated, respectively, at 13.35 (95\% CI: 7.58-23.51) versus 37.73 (95\% CI: 24.34-58.48) per 10,000 person-weeks over a total follow-up time of 8,989.1 and 5,301.0 person-weeks, respectively. 
medRxiv preprint doi: https://doi.org/10.1101/2021.08.07.21261578; this version posted August 9, 2021. The copyright holder for this preprint (which was not certified by peer review) is the author/funder, who has granted medRxiv a license to display the preprint in perpetuity.

All rights reserved. No reuse allowed without permission.

The hazard ratio adjusted for age, sex, nationality group, and the competing risks of vaccination and death was 0.53 (95\% CI: 0.26-1.08). Vaccine effectiveness against any SARS-CoV-2 infection, symptomatic or asymptomatic, was derived using the equation, 1- hazard ratio, and was estimated at 46.6\% (95\% CI: 0.0-73.7\%). Vaccine effectiveness against any severe, critical, or fatal COVID-19 disease was estimated at 72.3\% (95\% CI: 0.0-90.9\%).

\section{Vaccine effectiveness at $\geq 42$ days and $\geq 56$ days after the second dose}

Analyses were repeated to estimate vaccine effectiveness at $\geq 42$ days and at $\geq 56$ days after the second dose, instead of at $\geq 14$ days after the second dose. Figures 3 and 4 show the cumulative incidence of infection including only the cohorts of individuals who completed $\geq 42$ days and $\geq 56$ days after the second vaccine dose, respectively, compared to that in the cohort of individuals with no vaccination record, adjusting for age, sex, nationality group, and the competing risks of vaccination and death. Cumulative incidence was assessed, respectively, at $1.60 \%$ (95\% CI: $0.72-3.15 \%)$ and $1.19 \%$ (95\% CI: $0.45-2.63 \%)$ among those vaccinated, versus $4.74 \%$ (95\% CI: 3.00-7.07\%) among those unvaccinated, after 120 days of follow-up.

Incidence rates of infection in the cohorts of individuals who completed $\geq 42$ days and $\geq 56$ days after the second vaccine dose and the cohort of individuals with no vaccination record, were estimated, respectively, at 9.99 (95\% CI: 4.76-20.95) and 8.26 (95\% CI: 3.44-19.86) per 10,000 person-weeks over a total follow-up time of 7,007.7 and 6,049.9 person-weeks, respectively, among those vaccinated, versus 37.73 (95\% CI: 24.34-58.48) per 10,000 person-weeks over a total follow-up time of 5,301.0 person-weeks among those unvaccinated.

Hazard ratios adjusted for age, sex, nationality group, and the competing risks of vaccination and death were estimated at 0.34 (95\% CI: 0.15-0.79) and 0.26 (95\% CI: 0.10-0.67), respectively. Vaccine effectiveness against any SARS-CoV-2 infection, symptomatic or asymptomatic, was 
medRxiv preprint doi: https://doi.org/10.1101/2021.08.07.21261578; this version posted August 9, 2021. The copyright holder for this preprint (which was not certified by peer review) is the author/funder, who has granted medRxiv a license to display the preprint in perpetuity.

All rights reserved. No reuse allowed without permission.

estimated at $66.0 \%$ (95\% CI: $21.3-85.3 \%$ ) in those who completed $\geq 42$ days, and at $73.9 \%$ (95\% CI: $33.0-89.9 \%$ ) in those who completed $\geq 56$ days. Vaccine effectiveness against any severe, critical, or fatal COVID-19 disease was estimated at $85.0 \%$ (95\% CI: 35.7-96.5\%) in those who completed $\geq 42$ days, and at $83.8 \%(95 \%$ CI: $31.3-96.2 \%)$ in those who completed $\geq 56$ days.

\section{Discussion}

Vaccine effectiveness reached considerable levels in immunosuppressed kidney transplant recipients, which were not far below those in the general population of Qatar. ${ }^{21-24}$ However, vaccine protection mounted slowly and did not reach a high level until several weeks after the second dose. Notably, the build-up of vaccine protection mirrored the slow development of antibodies in transplant recipients that has been previously reported..$^{3,5-9,11-14,16}$ Indeed, the majority of breakthrough infections in those vaccinated occurred in the first few weeks after receiving the first and/or second dose (note Figure 1 and events of infection among those vaccinated in Figure 2). Strikingly, no breakthrough infection was recorded in those who were already fully vaccinated before February 1, 2021, the start day of follow-up in this study (Cohort B-I in Figure 1).

Vaccine effectiveness appeared stronger against hospitalization and death than against infection, a finding consistent with the pattern seen in the general population. ${ }^{21,23}$ Of 12 breakthrough infections documented among those vaccinated, four progressed to severe disease, none to critical disease, and none to COVID-19 death. Meanwhile, of 20 infections documented among unvaccinated persons, seven progressed to severe disease, six to critical disease, and none to COVID-19 death. Severe disease (acute-care hospitalization), critical disease (ICU hospitalization), and COVID-19 death were defined per World Health Organization guidelines $^{25,26}$ (Supplementary Text 2). 
This study has limitations. With the relatively small cohort of transplant recipients $(\mathrm{n}=782)$, and the rapid scale-up of vaccination during the study duration, it was not possible to match vaccinated and unvaccinated persons by factors such as age, sex, nationality, comorbidity, and calendar time, while maintaining adequate sample sizes, time of follow-up, and statistical precision. However, cohorts of both vaccinated and unvaccinated were largely balanced by both demographic and clinical characteristics (Table 1). Moreover, the regression analyses adjusted for age, sex, and nationality group, with age being a proxy for comorbidity, and both the adjusted and unadjusted analyses reached similar results (not shown). Additionally, the majority of individuals in both vaccinated and unvaccinated cohorts were followed during similar times, starting from the first day of the study, February 1, 2021, or shortly thereafter, even in the additional analyses of vaccine effectiveness for those at $\geq 42$ days and at $\geq 56$ days after the second vaccine dose. Please note follow up times (results and Figure 1) and numbers at risk (Figures 2-4).

We only assessed risk of documented infection, but other infections may have occurred and gone undocumented, perhaps because of minimal/mild or no symptoms. Unlike in blinded, randomized clinical trials, the investigated observational cohorts were not blinded nor randomized. Vaccine effectiveness estimates calculated in this study may not necessarily be generalizable to other solid organ transplant populations.

In conclusion, despite these limitations, the findings of this study demonstrate build-up of vaccine-induced protection in kidney transplant recipients, against both SARS-CoV-2 infection and COVID-19 disease, but this protection mounts slowly and does not reach a high level until several weeks after the second vaccine dose. While the present findings indicate that even immunosuppressed individuals benefit from vaccination, they suggest the need to develop better 
medRxiv preprint doi: https://doi.org/10.1101/2021.08.07.21261578; this version posted August 9, 2021. The copyright holder for this preprint (which was not certified by peer review) is the author/funder, who has granted medRxiv a license to display the preprint in perpetuity.

All rights reserved. No reuse allowed without permission.

strategies to enhance the protection in this group, such as exploring the addition of a third vaccine dose. 


\section{Acknowledgements}

We acknowledge the many dedicated individuals at Hamad Medical Corporation, the Ministry of Public Health, the Primary Health Care Corporation, and the Qatar Biobank for their diligent efforts and contributions to make this study possible. The authors are grateful for support from the Biomedical Research Program, the Biostatistics, Epidemiology, and Biomathematics Research Core, and the Genomics Core, all at Weill Cornell Medicine-Qatar, as well as for support provided by the Ministry of Public Health and Hamad Medical Corporation. The authors are also grateful for support from the Qatar Genome Programme for supporting the viral genome sequencing. Statements made herein are solely the responsibility of the authors. The funders of the study had no role in study design, data collection, data analysis, data interpretation, or writing of the article.

\section{Author contributions}

HC designed the study, performed the statistical analyses, and co-wrote the first draft of the article. LJA co-conceived and co-designed the study, led the statistical analyses, and co-wrote the first draft of the article. AAK co-conceived and co-designed the study. AAK, YA, HAM, OA, MMA, and JPJ constructed and populated the database of kidney transplant recipients. All authors contributed to data collection and acquisition, database development, discussion and interpretation of the results, literature reviews, and to the writing of the manuscript. All authors have read and approved the final manuscript.

\section{Competing interests}

Dr. Butt has received institutional grant funding from Gilead Sciences unrelated to the work presented in this paper. Otherwise, we declare no competing interests. 


\section{References}

1. $\quad$ Eberhardt CS, Balletto E, Cornberg M, Mikulska M. Coronavirus disease 2019 vaccination in transplant recipients. Curr Opin Infect Dis. 2021;34(4):275-287.

2. Khairallah P, Aggarwal N, Awan AA, et al. The impact of COVID-19 on kidney transplantation and the kidney transplant recipient - One year into the pandemic. Transpl Int. 2021;34(4):612-621.

3. Boyarsky BJ, Werbel WA, Avery RK, et al. Antibody Response to 2-Dose SARS-CoV-2 mRNA Vaccine Series in Solid Organ Transplant Recipients. JAMA. 2021;325(21):22042206.

4. Shostak Y, Shafran N, Heching M, et al. Early humoral response among lung transplant recipients vaccinated with BNT162b2 vaccine. Lancet Respir Med. 2021;9(6):e52-e53.

5. Sattler A, Schrezenmeier E, Weber UA, et al. Impaired humoral and cellular immunity after SARS-CoV-2 BNT162b2 (tozinameran) prime-boost vaccination in kidney transplant recipients. J Clin Invest. 2021;131(14).

6. Rincon-Arevalo H, Choi M, Stefanski AL, et al. Impaired humoral immunity to SARSCoV-2 BNT162b2 vaccine in kidney transplant recipients and dialysis patients. Sci Immunol. 2021;6(60).

7. Rabinowich L, Grupper A, Baruch R, et al. Low immunogenicity to SARS-CoV-2 vaccination among liver transplant recipients. J Hepatol. 2021;75(2):435-438.

8. Benotmane I, Gautier G, Perrin P, et al. Antibody Response After a Third Dose of the mRNA-1273 SARS-CoV-2 Vaccine in Kidney Transplant Recipients With Minimal Serologic Response to 2 Doses. JAMA. 2021.

9. Grupper A, Rabinowich L, Schwartz D, et al. Reduced humoral response to mRNA SARS-CoV-2 BNT162b2 vaccine in kidney transplant recipients without prior exposure to the virus. Am J Transplant. 2021.

10. Boyarsky BJ, Werbel WA, Avery RK, et al. Immunogenicity of a Single Dose of SARSCoV-2 Messenger RNA Vaccine in Solid Organ Transplant Recipients. JAMA. 2021;325(17):1784-1786.

11. Benotmane I, Gautier-Vargas G, Cognard N, et al. Weak anti-SARS-CoV-2 antibody response after the first injection of an mRNA COVID-19 vaccine in kidney transplant recipients. Kidney Int. 2021;99(6):1487-1489.

12. Korth J, Jahn M, Dorsch O, et al. Impaired Humoral Response in Renal Transplant Recipients to SARS-CoV-2 Vaccination with BNT162b2 (Pfizer-BioNTech). Viruses. 2021;13(5).

13. Benotmane I, Gautier-Vargas G, Cognard N, et al. Low immunization rates among kidney transplant recipients who received 2 doses of the mRNA-1273 SARS-CoV-2 vaccine. Kidney Int. 2021;99(6):1498-1500.

14. Yi SG, Knight RJ, Graviss EA, et al. Kidney Transplant Recipients Rarely Show an Early Antibody Response Following the First COVID-19 Vaccine Administration. Transplantation. 2021;105(7):e72-e73.

15. Narasimhan M, Mahimainathan L, Clark AE, et al. Serological Response in Lung Transplant Recipients after Two Doses of SARS-CoV-2 mRNA Vaccines. medRxiv. 2021:2021.2004.2026.21255926. 
medRxiv preprint doi: https://doi.org/10.1101/2021.08.07.21261578; this version posted August 9, 2021. The copyright holder for this preprint (which was not certified by peer review) is the author/funder, who has granted medRxiv a license to display the preprint in perpetuity. All rights reserved. No reuse allowed without permission.

16. Ben-Dov IZ, Oster Y, Tzukert K, et al. Impact of tozinameran (BNT162b2) mRNA vaccine on kidney transplant and chronic dialysis patients: 3-5 months followup. medRxiv. 2021:2021.2006.2012.21258813.

17. Lemieux JE, Li A, Gentili M, et al. Vaccine serologic responses among transplant patients associate with COVID-19 infection and T peripheral helper cells. medRxiv. 2021:2021.2007.2011.21260338.

18. Prendecki M, Thomson T, Clarke CL, et al. Comparison of humoral and cellular responses in kidney transplant recipients receiving BNT162b2 and ChAdOx1 SARSCoV-2 vaccines. medRxiv. 2021:2021.2007.2009.21260192.

19. Polack FP, Thomas SJ, Kitchin N, et al. Safety and Efficacy of the BNT162b2 mRNA Covid-19 Vaccine. N Engl J Med. 2020.

20. Baden LR, El Sahly HM, Essink B, et al. Efficacy and Safety of the mRNA-1273 SARSCoV-2 Vaccine. N Engl J Med. 2021;384(5):403-416.

21. Abu-Raddad LJ, Chemaitelly H, Butt AA, National Study Group for Covid-19 Vaccination. Effectiveness of the BNT162b2 Covid-19 Vaccine against the B.1.1.7 and B.1.351 Variants. N Engl J Med. 2021.

22. Abu-Raddad LJ, Chemaitelly H, Yassine HM, et al. Pfizer-BioNTech mRNA BNT162b2 Covid-19 vaccine protection against variants of concern after one versus two doses. $J$ Travel Med. 2021.

23. Chemaitelly H, Yassine HM, Benslimane FM, et al. mRNA-1273 COVID-19 vaccine effectiveness against the B.1.1.7 and B.1.351 variants and severe COVID-19 disease in Qatar. Nat Med. 2021.

24. Bertollini R, Chemaitelly H, Yassine HM, Al-Thani MH, Al-Khal A, Abu-Raddad LJ. Associations of Vaccination and of Prior Infection With Positive PCR Test Results for SARS-CoV-2 in Airline Passengers Arriving in Qatar. JAMA. 2021.

25. World Health Organization. COVID-19 clinical management: living guidance. Available from: https://www.who.int/publications/i/item/WHO-2019-nCoV-clinical-2021-1. Accessed on: May 15 2021. 2021.

26. World Health Organization. International guidelines for certification and classification (coding) of COVID-19 as cause of death. Available from:

https://www.who.int/classifications/icd/Guidelines_Cause_of_Death_COVID-1920200420-EN.pdf?ua=1. Document Number: WHO/HQ/DDI/DNA/CAT. Accessed on May 31, 2021. 2021.

27. World Health Organization. Tracking SARS-CoV-2 variants. Available from: https://www.who.int/en/activities/tracking-SARS-CoV-2-variants/. Accessed on: June 5, 2021. 2021.

28. National Project of Surveillance for Variants of Concern and Viral Genome Sequencing. Qatar viral genome sequencing data. Data on randomly collected samples. https://www.gisaid.org/phylodynamics/global/nextstrain/. https://www.gisaid.org/phylodynamics/global/nextstrain/. Published 2021. Accessed.

29. Benslimane FM, Al Khatib HA, Al-Jamal O, et al. One year of SARS-CoV-2: Genomic characterization of COVID-19 outbreak in Qatar. medRxiv. 2021:2021.2005.2019.21257433.

30. Hasan MR, Kalikiri MKR, Mirza F, et al. Real-Time SARS-CoV-2 Genotyping by HighThroughput Multiplex PCR Reveals the Epidemiology of the Variants of Concern in Qatar. medRxiv. 2021:2021.2007.2018.21260718. 
medRxiv preprint doi: https://doi.org/10.1101/2021.08.07.21261578; this version posted August 9, 2021. The copyright holder for this preprint

(which was not certified by peer review) is the author/funder, who has granted medRxiv a license to display the preprint in perpetuity.

All rights reserved. No reuse allowed without permission.

31. Abu-Raddad LJ, Chemaitelly H, Ayoub HH, et al. Characterizing the Qatar advancedphase SARS-CoV-2 epidemic. Scientific Reports. 2021;11(1):6233.

32. Ayoub HH, Chemaitelly H, Seedat S, et al. Mathematical modeling of the SARS-CoV-2 epidemic in Qatar and its impact on the national response to COVID-19. J Glob Health. 2021;11:05005.

33. Fine JP, Gray RJ. A Proportional Hazards Model for the Subdistribution of a Competing Risk. Journal of the American Statistical Association. 1999;94(446):496-509.

34. Coyle PV, Chemaitelly H, Kacem M, et al. SARS-CoV-2 seroprevalence in the urban population of Qatar: An analysis of antibody testing on a sample of 112,941 individuals. iScience. 2021:102646.

35. Al-Thani MH, Farag E, Bertollini R, et al. SARS-CoV-2 infection is at herd immunity in the majority segment of the population of Qatar. Open Forum Infectious Diseases. 2021.

36. Jeremijenko A, Chemaitelly H, Ayoub HH, et al. Herd Immunity against Severe Acute Respiratory Syndrome Coronavirus 2 Infection in 10 Communities, Qatar. Emerg Infect Dis. 2021;27(5):1343-1352.

37. Abu-Raddad LJ, Dargham S, Chemaitelly H, et al. COVID-19 risk score as a public health tool to guide targeted testing: A demonstration study in Qatar. medRxiv. 2021:2021.2003.2006.21252601.

38. StataCorp. Stata Statistical Software: Release 17. College Station, TX: StataCorp LLC. 2021.

39. Planning and Statistics Authority-State of Qatar. Qatar Monthly Statistics. Available from: https://www.psa.gov.qa/en/pages/default.aspx. Accessed on: May 26, 2020. 2020. 
Figure 1. Flowchart showing the selection process for the study population. Light blue color indicates persons who entered the study unvaccinated, but who were subsequently vaccinated and followed up as part of the cohort of vaccinated individuals. Light yellow color indicates final outcomes for the full Cohort B of vaccinated individuals, including Cohort B-I and Cohort B-II.

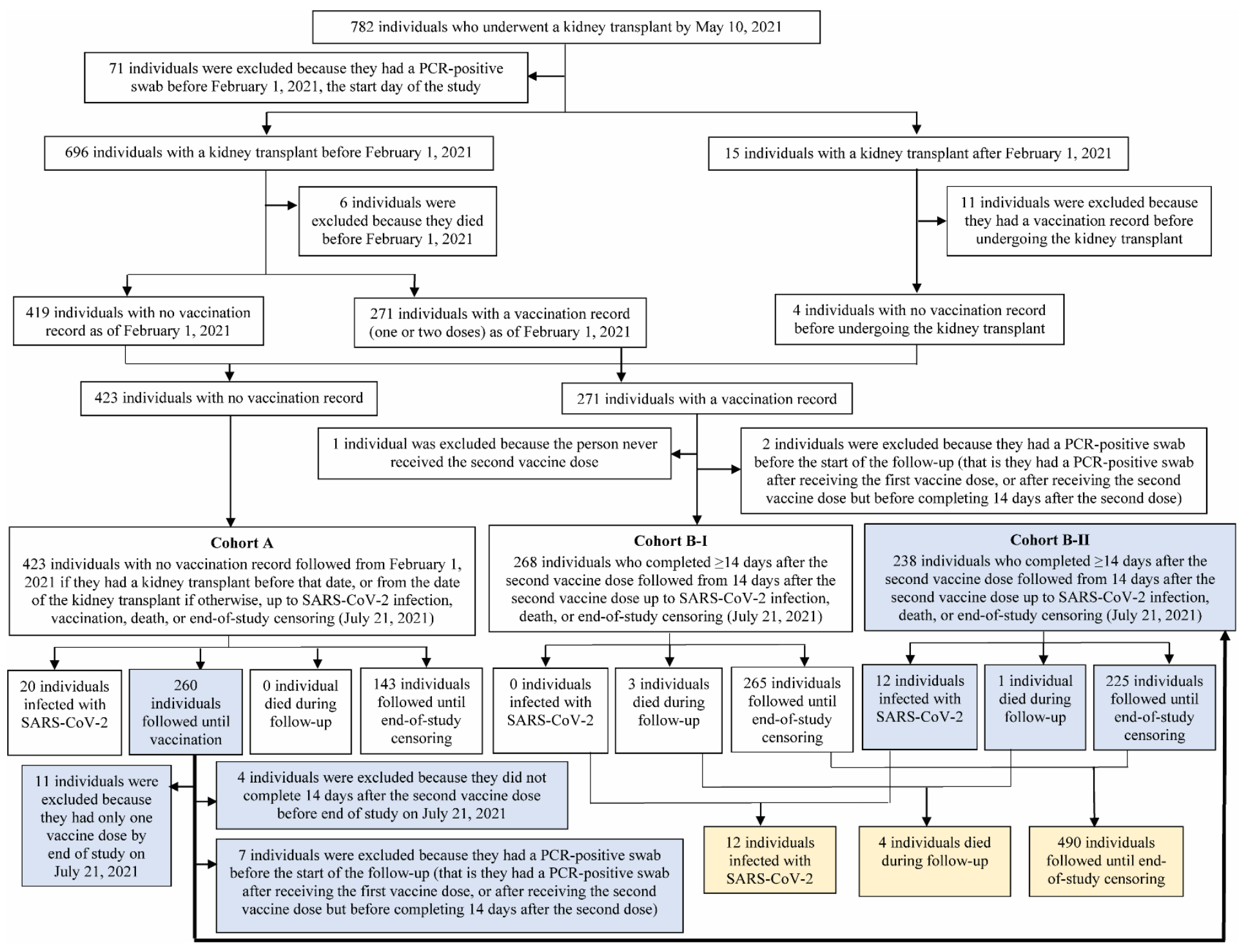


Table 1. Demographic and clinical characteristics of study cohorts.

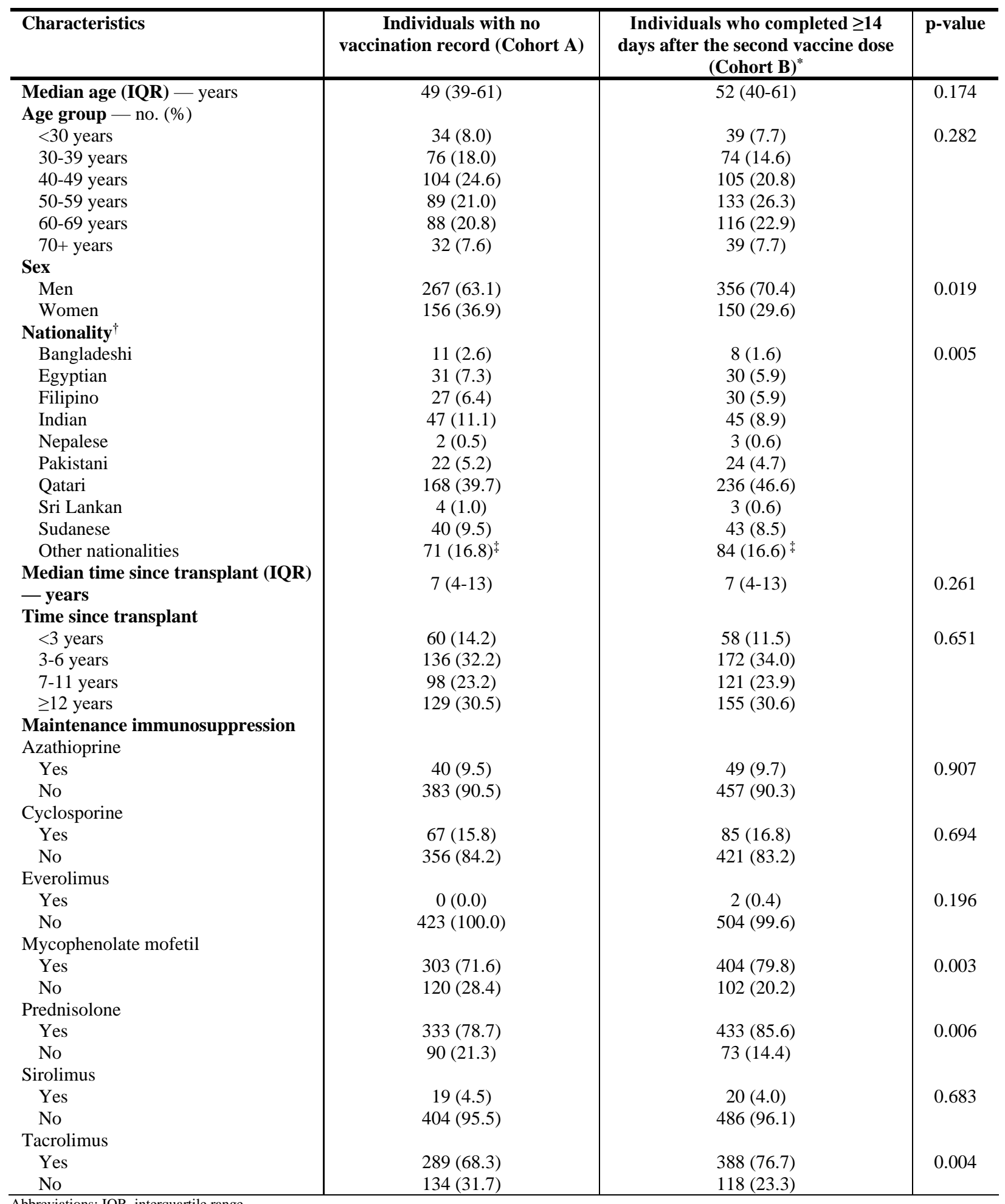

Abbreviations: IQR, interquartile range.

*This group includes all vaccinated individuals who completed $\geq 14$ days after the second vaccine dose in the cross-over design.

Nationalities were chosen to represent the most populous groups in the population of Qatar.

†These comprise 18 other nationalities among individuals with no vaccination record, and 24 other nationalities among individuals who completed $\geq 14$ days after the second vaccine dose. 
Figure 2. Cumulative risk (incidence) of documented SARS-CoV-2 infection in the cohort of vaccinated individuals who completed $\geq 14$ days after the second vaccine dose, compared to that of documented infection in the cohort of individuals with no vaccination record, calculated using the Fine-Gray model to account for the competing risks of vaccination and death, and after adjustment for age, sex, and nationality group. Follow-up extended from February 1 or the organ transplant date (which ever came first) for the cohort of unvaccinated individuals, and from 14 days after the second vaccine dose for the cohort of vaccinated individuals, both up to July 21, 2021.

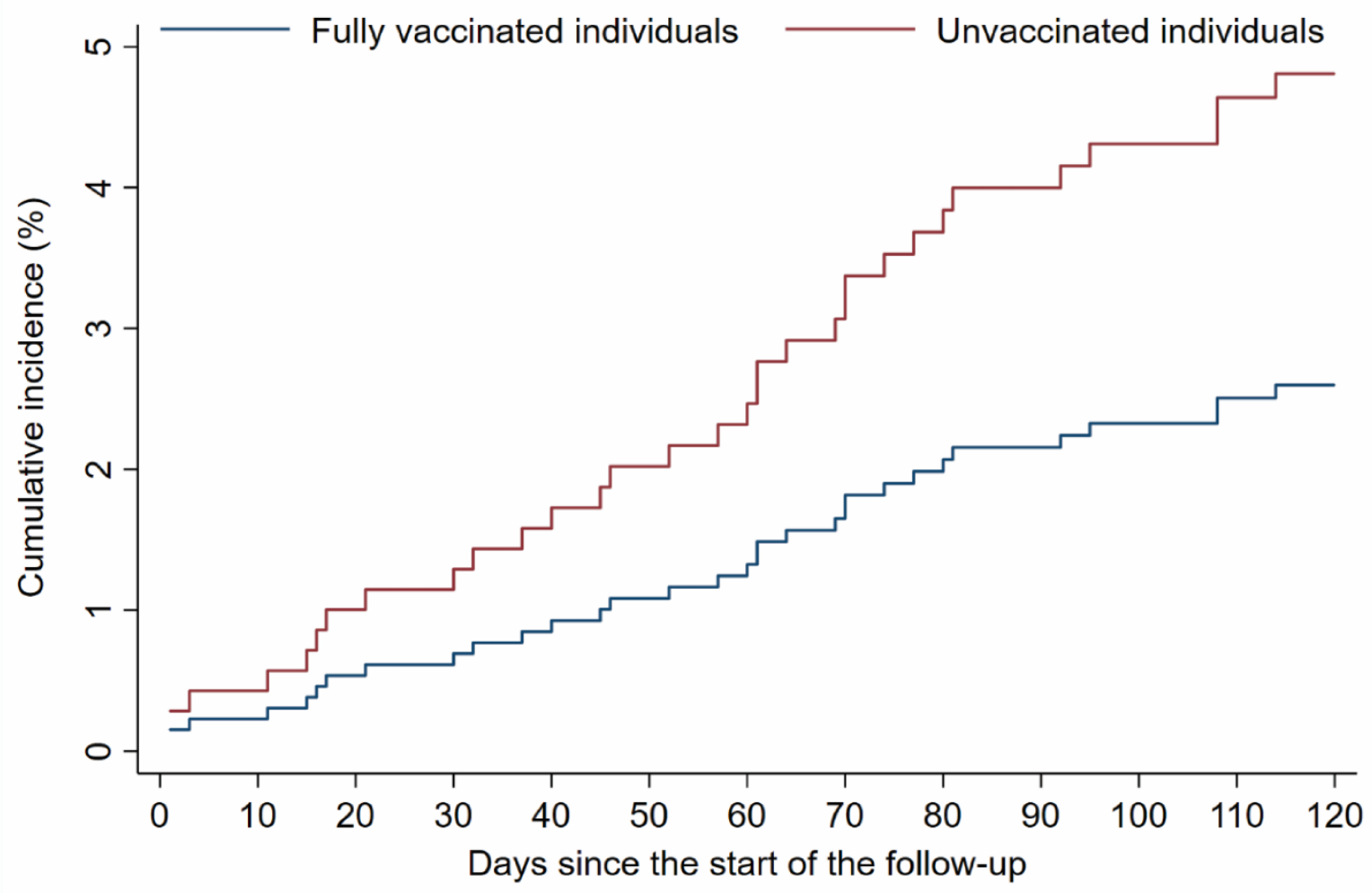

\begin{tabular}{l|l|l|l|l|l|l|l|l|l|l|l|l|l}
\hline Time (Days) & $\mathbf{0}$ & $\mathbf{1 0}$ & $\mathbf{2 0}$ & $\mathbf{3 0}$ & $\mathbf{4 0}$ & $\mathbf{5 0}$ & $\mathbf{6 0}$ & $\mathbf{7 0}$ & $\mathbf{8 0}$ & $\mathbf{9 0}$ & $\mathbf{1 0 0}$ & $\mathbf{1 1 0}$ & $\mathbf{1 2 0}$ \\
\hline No. at risk \\
\hline Fully vaccinated & 506 & 500 & 494 & 485 & 475 & 465 & 454 & 433 & 415 & 410 & 399 & 371 & 326 \\
\hline Unvaccinated & 423 & 384 & 342 & 287 & 260 & 254 & 238 & 210 & 194 & 189 & 177 & 172 & 160 \\
\hline Cumulative No. of events \\
\hline Fully vaccinated & 0 & 2 & 5 & 6 & 7 & 7 & 7 & 9 & 10 & 11 & 11 & 12 & 12 \\
\hline Unvaccinated & 0 & 1 & 2 & 3 & 5 & 7 & 10 & 14 & 16 & 16 & 18 & 19 & 20 \\
\hline
\end{tabular}


Figure 3. Cumulative risk (incidence) of documented SARS-CoV-2 infection in the cohort of vaccinated individuals who completed $\geq 42$ days after the second vaccine dose, compared to that of documented infection in the cohort of individuals with no vaccination record, calculated using the Fine-Gray model to account for the competing risks of vaccination and death, and after adjustment for age, sex, and nationality group. Follow-up extended from February 1 or the organ transplant date (which ever came first) for the cohort of unvaccinated individuals, and from 42 days after the second vaccine dose for the cohort of vaccinated individuals, both up to July 21, 2021.

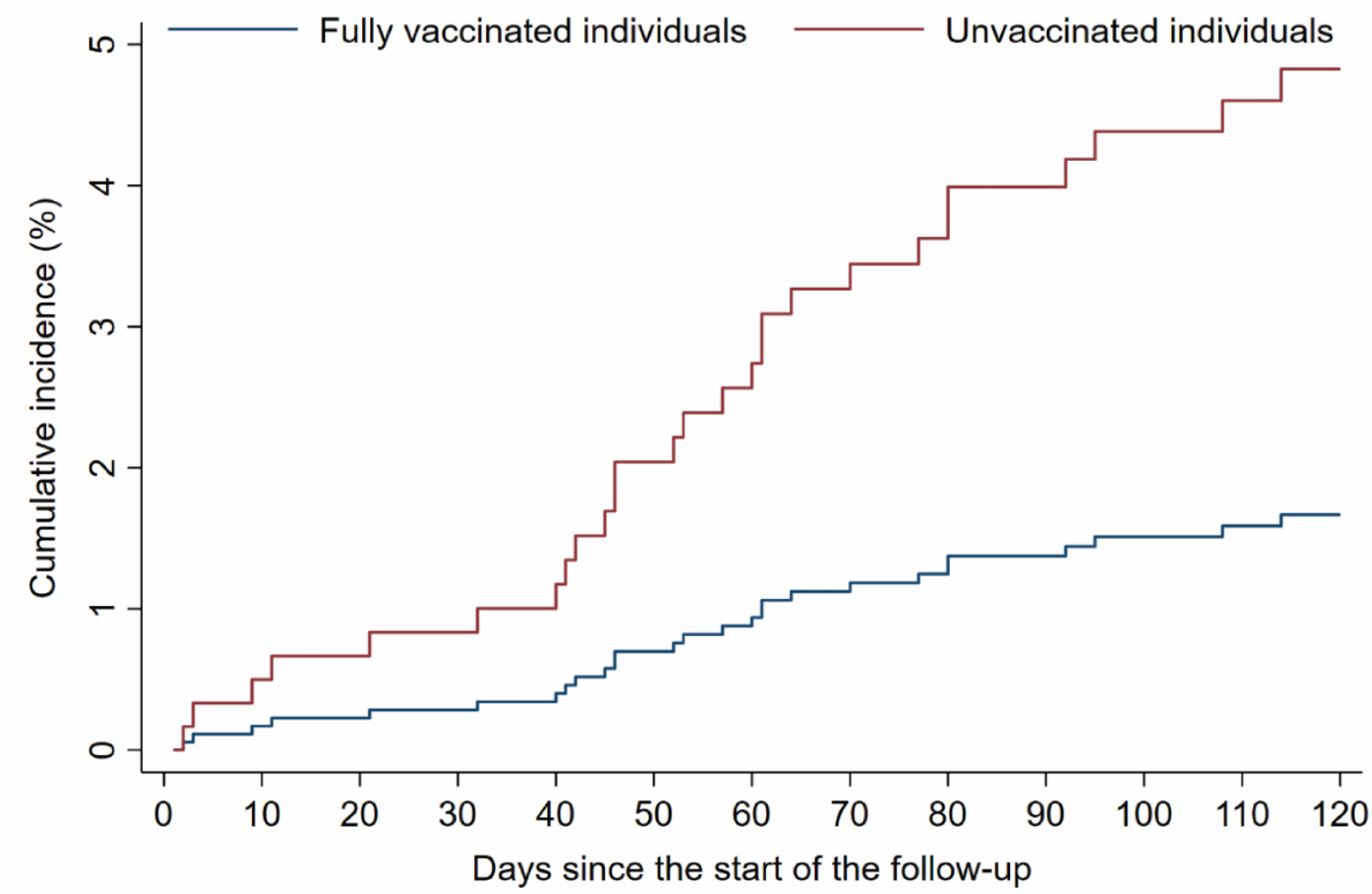

\begin{tabular}{|c|c|c|c|c|c|c|c|c|c|c|c|c|c|}
\hline Time (Days) & $\mathbf{0}$ & 10 & 20 & 30 & 40 & 50 & 60 & 70 & 80 & 90 & 100 & 110 & 120 \\
\hline \multicolumn{14}{|l|}{ No. at risk } \\
\hline Fully vaccinated & 487 & 477 & 470 & 458 & 439 & 416 & 412 & 402 & 379 & 330 & 293 & 252 & 192 \\
\hline Unvaccinated & 423 & 384 & 342 & 287 & 260 & 254 & 238 & 210 & 194 & 189 & 177 & 172 & 160 \\
\hline \multicolumn{14}{|c|}{ Cumulative No. of events } \\
\hline Fully vaccinated & 0 & 2 & 2 & 2 & 2 & 5 & 6 & 6 & 7 & 7 & 7 & 7 & 7 \\
\hline Unvaccinated & 0 & 1 & 2 & 3 & 5 & 7 & 10 & 14 & 16 & 16 & 18 & 19 & 20 \\
\hline
\end{tabular}


Figure 4. Cumulative risk (incidence) of documented SARS-CoV-2 infection in the cohort of vaccinated individuals who completed $\geq 56$ days after the second vaccine dose, compared to that of documented infection in the cohort of individuals with no vaccination record, calculated using the Fine-Gray model to account for the competing risks of vaccination and death, and after adjustment for age, sex, and nationality group. Follow-up extended from February 1 or the organ transplant date (which ever came first) for the cohort of unvaccinated individuals, and from 56 days after the second vaccine dose for the cohort of vaccinated individuals, both up to July $21,2021$.

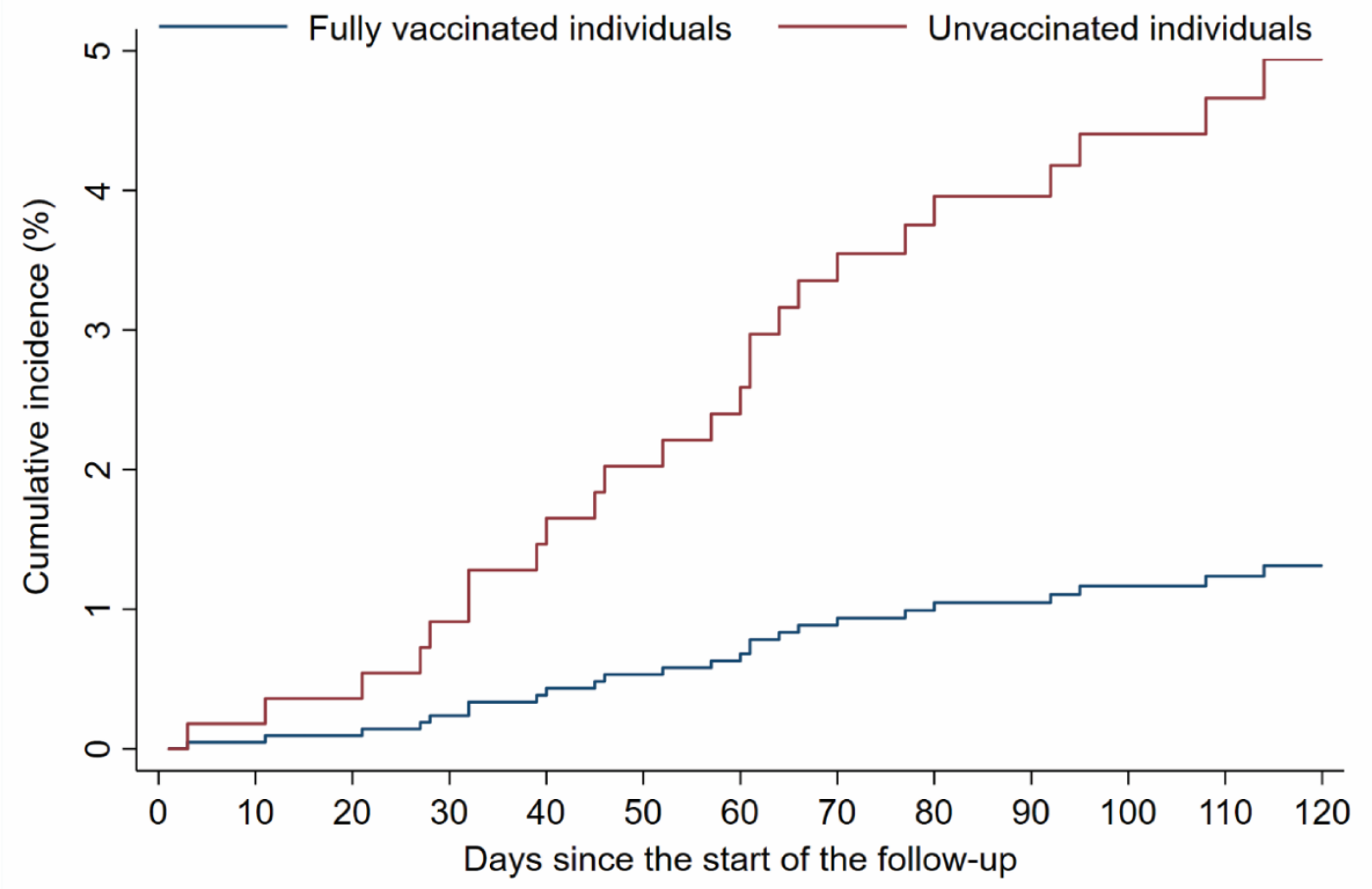

\begin{tabular}{|c|c|c|c|c|c|c|c|c|c|c|c|c|c|}
\hline Time (Days) & $\mathbf{0}$ & 10 & 20 & 30 & 40 & 50 & 60 & 70 & 80 & 90 & 100 & 110 & 120 \\
\hline \multicolumn{14}{|l|}{ No. at risk } \\
\hline Fully vaccinated & 473 & 464 & 451 & 430 & 413 & 410 & 392 & 368 & 320 & 281 & 237 & 166 & 91 \\
\hline Unvaccinated & 423 & 384 & 342 & 287 & 260 & 254 & 238 & 210 & 194 & 189 & 177 & 172 & 160 \\
\hline \multicolumn{14}{|c|}{ Cumulative No. of events } \\
\hline Fully vaccinated & 0 & 0 & 0 & 2 & 4 & 4 & 4 & 5 & 5 & 5 & 5 & 5 & 5 \\
\hline Unvaccinated & 0 & 1 & 2 & 3 & 5 & 7 & 10 & 14 & 16 & 16 & 18 & 19 & 20 \\
\hline
\end{tabular}




\section{Supplementary Material}

\section{Table of Contents}

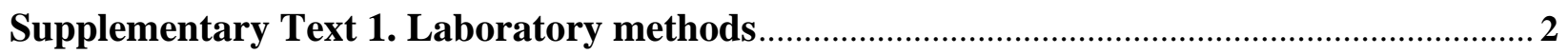

Supplementary Text 2. COVID-19 severity, criticality, and fatality classification................. 3

Supplementary Table 1. STROBE checklist for cohort studies ............................................. 4

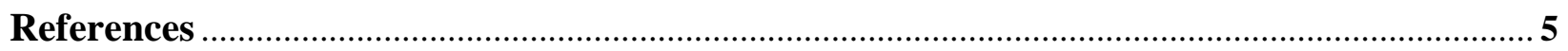


medRxiv preprint doi: https://doi.org/10.1101/2021.08.07.21261578; this version posted August 9, 2021. The copyright holder for this preprint (which was not certified by peer review) is the author/funder, who has granted medRxiv a license to display the preprint in perpetuity.

All rights reserved. No reuse allowed without permission.

\section{Supplementary Text 1. Laboratory methods}

Nasopharyngeal and/or oropharyngeal swabs (Huachenyang Technology, China) were collected for PCR testing and placed in Universal Transport Medium (UTM). Aliquots of UTM were: extracted on a QIAsymphony platform (QIAGEN, USA) and tested with RT-qPCR using TaqPath ${ }^{\mathrm{TM}}$ COVID-19 Combo Kits (100\% sensitivity and specificity; ${ }^{1}$ Thermo Fisher Scientific, USA) on an ABI 7500 FAST (ThermoFisher, USA); extracted using a custom protocol ${ }^{2}$ on a Hamilton Microlab STAR (Hamilton, USA) and tested using AccuPower SARS-CoV-2 RealTime RT-PCR Kits (100\% sensitivity and specificity; ${ }^{3}$ Bioneer, Korea) on an ABI 7500 FAST; or loaded directly into a Roche cobas ${ }^{\circledR} 6800$ system and assayed with a cobas ${ }^{\circledR}$ SARS-CoV-2 Test (95\% sensitivity, $100 \%$ specificity; ${ }^{4}$ Roche, Switzerland). The first assay targets the viral S, $\mathrm{N}$, and ORF1ab regions. The second targets the viral RdRp and E-gene regions, and the third targets the ORF1ab and E-gene regions.

All tests were conducted at the HMC Central Laboratory or Sidra Medicine Laboratory, following standardized protocols. 
medRxiv preprint doi: https://doi.org/10.1101/2021.08.07.21261578; this version posted August 9, 2021. The copyright holder for this preprint (which was not certified by peer review) is the author/funder, who has granted medRxiv a license to display the preprint in perpetuity.

All rights reserved. No reuse allowed without permission.

\section{Supplementary Text 2. COVID-19 severity, criticality, and fatality classification}

Severe COVID-19 disease was defined per WHO classification as a SARS-CoV-2 infected person with "oxygen saturation of $<90 \%$ on room air, and/or respiratory rate of $>30$

breaths/minute in adults and children $>5$ years old (or $\geq 60$ breaths/minute in children $<2$ months old or $\geq 50$ breaths/minute in children $2-11$ months old or $\geq 40$ breaths/minute in children $1-5$ years old), and/or signs of severe respiratory distress (accessory muscle use and inability to complete full sentences, and, in children, very severe chest wall indrawing, grunting, central cyanosis, or presence of any other general danger signs)". ${ }^{5}$ Detailed WHO criteria for classifying SARS-CoV-2 infection severity can be found in the WHO technical report. ${ }^{5}$

Critical COVID-19 disease was defined per WHO classification as a SARS-CoV-2 infected person with "acute respiratory distress syndrome, sepsis, septic shock, or other conditions that would normally require the provision of life sustaining therapies such as mechanical ventilation (invasive or non-invasive) or vasopressor therapy". ${ }^{5}$ Detailed WHO criteria for classifying SARS-CoV-2 infection criticality can be found in the WHO technical report. ${ }^{5}$

COVID-19 death was defined per WHO classification as "a death resulting from a clinically compatible illness, in a probable or confirmed COVID-19 case, unless there is a clear alternative cause of death that cannot be related to COVID-19 disease (e.g. trauma). There should be no period of complete recovery from COVID-19 between illness and death. A death due to COVID19 may not be attributed to another disease (e.g. cancer) and should be counted independently of preexisting conditions that are suspected of triggering a severe course of COVID-19". Detailed WHO criteria for classifying COVID-19 death can be found in the WHO technical report. ${ }^{6}$ 


\section{Supplementary Table 1. STROBE checklist for cohort studies.}

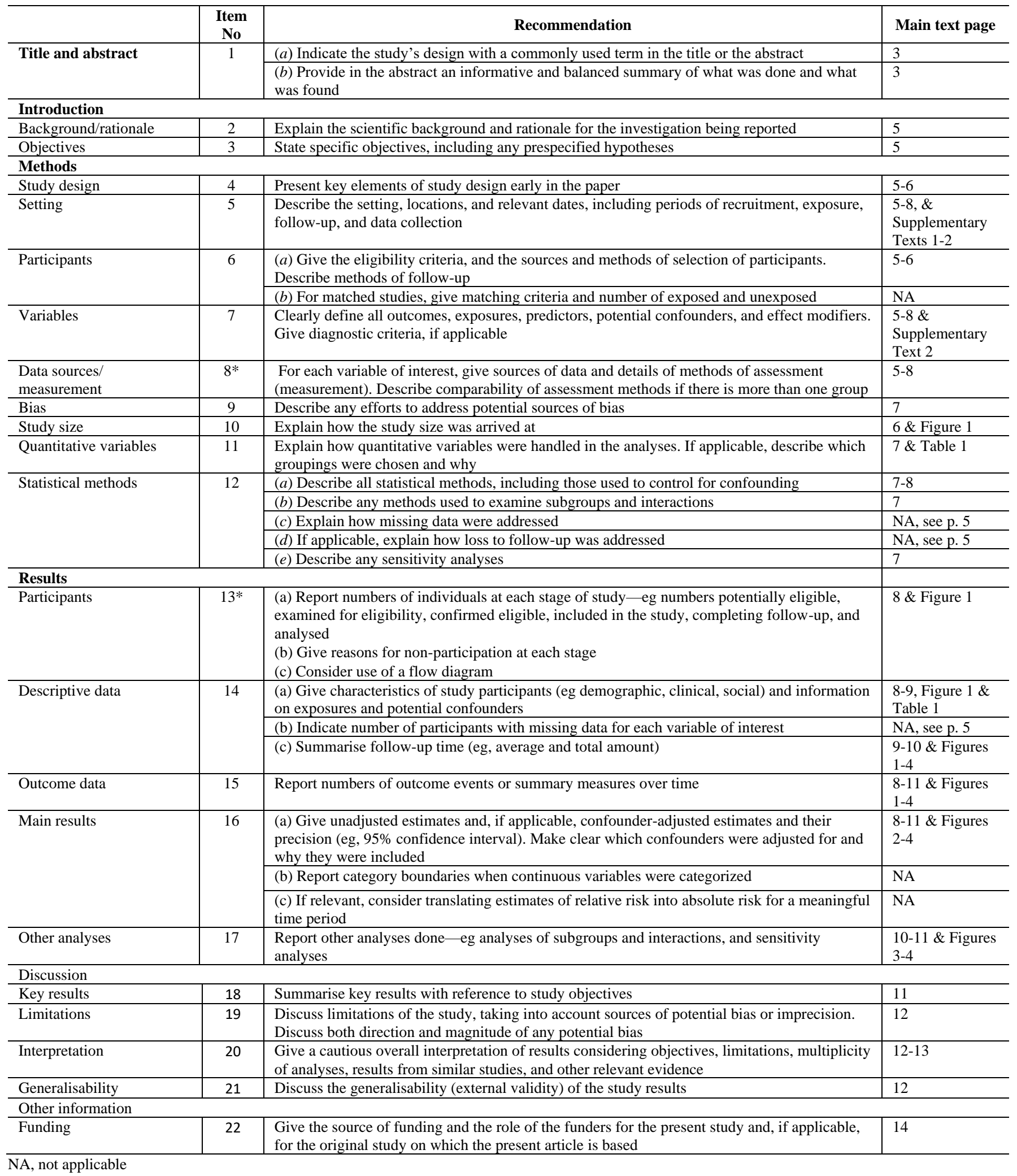


medRxiv preprint doi: https://doi.org/10.1101/2021.08.07.21261578; this version posted August 9, 2021. The copyright holder for this preprint (which was not certified by peer review) is the author/funder, who has granted medRxiv a license to display the preprint in perpetuity.

All rights reserved. No reuse allowed without permission. 
medRxiv preprint doi: https://doi.org/10.1101/2021.08.07.21261578; this version posted August 9, 2021. The copyright holder for this preprint (which was not certified by peer review) is the author/funder, who has granted medRxiv a license to display the preprint in perpetuity.

All rights reserved. No reuse allowed without permission.

\section{References}

1. Thermo Fisher Scientific. TaqPath ${ }^{\mathrm{TM}}$ COVID-19 CE-IVD RT-PCR Kit instructions for use. Available from: https://assets.thermofisher.com/TFSAssets/LSG/manuals/MAN0019215_TaqPathCOVID-19_CE-IVD_RT-PCR\%20Kit_IFU.pdf. Accessed on December 02, 2020. 2020;

2. Kalikiri MKR, Hasan MR, Mirza F, Xaba T, Tang P, Lorenz S. High-throughput extraction of SARS-CoV-2 RNA from nasopharyngeal swabs using solid-phase reverse immobilization beads. medRxiv. 2020:2020.04.08.20055731. doi:10.1101/2020.04.08.20055731 3. Kubina R, Dziedzic A. Molecular and Serological Tests for COVID-19 a Comparative Review of SARS-CoV-2 Coronavirus Laboratory and Point-of-Care Diagnostics. Diagnostics (Basel). Jun 26 2020;10(6)doi:10.3390/diagnostics10060434

4. US Food and Drug Administration. Cobas® SARS-CoV-2: Qualitative assay for use on the cobas@ 6800/8800 Systems. Avilable from: https://www.fda.gov/media/136049/download. Accessed on: December 02, 2020. 2020;

5. World Health Organization. COVID-19 clinical management: living guidance. Available from: https://www.who.int/publications/i/item/WHO-2019-nCoV-clinical-2021-1. Accessed on: May 15 2021. 2021;

6. World Health Organization. International guidelines for certification and classification (coding) of COVID-19 as cause of death. Available from:

https://www.who.int/classifications/icd/Guidelines_Cause_of_Death_COVID-19-20200420EN.pdf?ua=1. Document Number: WHO/HQ/DDI/DNA/CAT. Accessed on May 31, 2021. 2021; 